УДК 621.22

\title{
ГІДРАВЛІЧНИЙ НАСОС 3 РЕГУЛЬОВАНОЮ ПОДАЧЕЮ ДЛЯ ТРАНСПОРТНИХ ЗАСОБІВ
}

\author{
Канд. техн. наук М.Б. Чубикало \\ ГИДРАВЛИЧЕСКИЙ НАСОС С РЕГУЛИРУЕМОЙ ПОДАЧЕЙ ДЛЯ \\ ТРАНСПОРТНЫХ СРЕДСТВ
}

\section{Канд. техн. наук М.Б. Чубыкало \\ HYDRAULIC PUMP CONTROLLED FEED FOR VEHICLES}

\author{
Cand. of techn. sciences M.B. Chubikalo
}

Проаналізовані недоліки регулювання частоти обертання вентиляторів охолодження радіаторів дизеля зміненням подачі рідини в гідромотори способом зливу частини потоку назад у впускну магістраль, щзо є енергетично не ефективним. Запропонована та показана конструкція і описаний приниип роботи механічної системи гідравлічного насоса біроторно шиберного типу з регульованою подачею способом зміни ексиентриситету взаємного розташування ротора і корпуса.

Ключові слова: тепловози, охолодження радіаторів дизеля, гідростатичний привод, гідравлічний біроторно шиберний насос, регулювання продуктивності.

Проанализированы недостатки регулирования частоты вращения вентиляторов охлаждения радиаторов дизеля изменением подачи жидкости в гидромоторы способом слива части потока обратно во впускную магистраль, что есть энергетически неэффективно. Предложена и показана конструкиия $u$ описан принцип работь механической системы гидравлического насоса бироторно шиберного типа с регулируемой подачей способом изменения эксиентриситета взаимного расположения ротора и корпуса.

Ключевые слова: тепловозы, охлаждение радиаторов дизеля, гидростатический привод, гидравлический бироторно ииберный насос, регулирование производительности.

On locomotives TEP60 [2 ], [ TEP70 3 ], TH16, for cooling radiators used diesel hydrostatic drive using the same volume of hydraulic machines axial - piston type. Adjust fan speed by changing the feed fluid motors way of shower flow back into the inlet manifold, ie, decreasing volumetric efficiency, which is directly related to the decrease in overall efficiency, because energy is not efficient. In the Ukrainian State Academy of Railway Transport developed hydraulic valves birotorno machine parameters which significantly exceed those machines axial - piston type. This machine can serve as hydraulic pumps, and hydraulic. Manage revolution hydraulic fan drive should do the adjustment hydraulic pumps. The design of the hydraulic valves birotorno machine allows you to adjust the performance shift mode eccentricity relative position of the rotor and the housing, thereby increasing the efficiency of hydraulic drive.

Keywords: locomotives, diesel engine cooling radiators, hydrostatic drive, hydraulic birotorno vane pump, capacity control.

Вступ. Однією з основних вимог до сучасних транспортних засобів $\epsilon$ збільшення їх потужності, швидкості, надійності при зниженні матеріаломісткості конструкції, зниженні собівартості та експлуатаційних витрат. Прагнення до 
найбільш повного задоволення цих вимог означає необхідність удосконалення агрегатів, які входять до складу транспортних засобів. До таких агрегатів можна віднести гідравлічні машини. Гідравлічні машини, крім того, широко застосовуються в інших галузях народного господарства (будівельні машини, авіація, автомобілі тощо). Це визначає актуальність робіт, які спрямовані на удосконалення конструкції гідравлічних машин.

Постановка проблеми у загальному вигляді та іï зв'язок із важливими науковими та практичними завданнями. На тепловозах ТЕП60 [2], ТЕП70 [3], ТГ16 та ін. для охолодження радіаторів дизеля застосовується гідростатичний привод 3 використанням однакових гідравлічних машин об'ємної дії аксіально-поршневого типу МН-250/100. Тепловози ТЕП70 і ТГ16 мають по шість, а ТЕП60 мають по чотири гідромашини. Потужність від колінчастого вала дизеля через редуктор передається половині 3 машин, що працюють як гідронасоси, інша половина, від них, працює як гідромотори привода вентиляторних коліс. Робоча рідина засмоктується гідронасосами 3 бака i нагнітається в гідромотори під тиском 4 10 МПа. Регулювання частоти обертання вентиляторів здійснюється зміненням подачі рідини в гідромотори способом зливу частини потоку назад у впускну магістраль, тобто зниженням об'ємного ККД, а це напряму пов'язано зі зниженням загального ККД, тому енергетично не ефективно [5].

Аналіз останніх досліджень i публікацій. В Українській державній академії залізничного транспорту розроблена гідравлічна біроторно шиберна машина (ГБШМ) [7], показники якої значно перевищують показники машин аксіальнопоршневого типу. Ця машина може виконувати функції як гідронасоса, так і гідромотора.

Керування обертами гідромоторів привода вентиляторів доцільно робити регулюванням продуктивності гідронасосів [5]. Конструкція гідравлічної біроторно шиберної машини дозволяє регулювати продуктивність способом зміни ексцентриситету взаємного розташування ротора i корпуса [7]. Такий спосіб регулювання не знижує ККД гідропривода, який може досягати $96 \%$.

$\begin{array}{ccc}\text { Визначення } & \text { мети } & \text { та задачi } \\ \text { дослідження. } & \text { Стаття } & \text { присвячена }\end{array}$ висвітленню конструкції гідравлічного біроторно шиберного насоса 3 пристроєм для керування обертами гідромоторів способом зміни ексцентриситету взаємного розташування ротора та корпуса.

Основна частина досліджень. На рисунку схематично зображено загальний вигляд ГБШМ зі змінним ексцентриситетом взаємного розташування ротора і корпуса.

ГБШМ із змінним ексцентриситетом містить циліндричний блок 1 , в якому на опорах обертання 3 встановлено корпус 4. На шийці осі 2, на опорах обертання 3 встановлений ротор 5 i поміщений $\mathrm{y}$ внутрішній об'єм корпуса 4. У корпусі 4 виконані радіальні пази 6 , в яких, 3 можливістю радіального переміщення, встановлені шибери 7. У зоні контакту шиберів 73 ротором 5 на його циліндричній поверхні виконані плоскі грані 8 і паралельно їм, тангенціально розташовані, прямокутні пази 9, в яких 3 можливістю тангенціального ковзання в них встановлені повзуни 10 , виконані заодно 3 шиберами 7. Між корпусом 4 i ротором 5 утворені робочі об'єми 11, які один від одного герметично відділені шиберами 7. Усередині ексцентрикової осі 2 виконані впускний колектор 12 і випускний колектор 13,3 можливістю сполучення з каналами 14 в роторі 5. Опори обертання 3 ротора 5 виконані у вигляді золотників - розподільників, і через канали 14 розподіляють засмоктування рідини 3 впускного колектора 12 в робочі об'єми 11 і нагнітання рідини у випускний колектор 13. Для подачі або зняття крутного моменту 
$\epsilon$ вал 15, жорстко зчленований з корпусом 4. Для зміни ексцентриситету вісь 2 має можливість поступального вертикального переміщення по пазу 16 в блоці 1 за допомогою дії на неї штока 17. Керування зміщенням осі 2 здійснюється приводом 18.

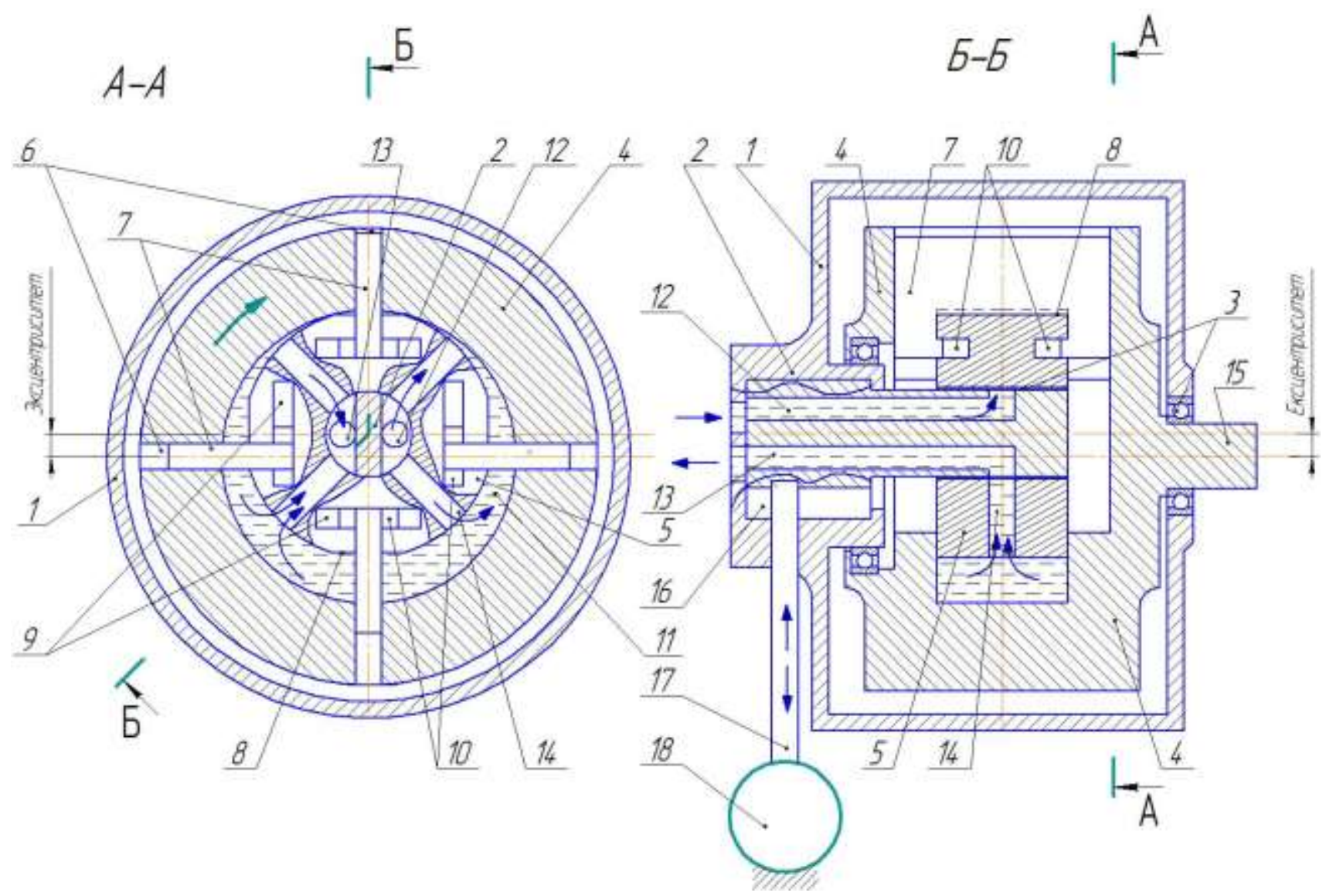

Рис. Гідравлічна біроторно шиберна машина зі змінним ексцентриситетом взаємного розташування ротора і корпуса

ГБШМ працює таким чином. При обертанні корпуса 4 i синхронізованого 3 ним ротора 5 відбувається зміна ємності герметичних робочих об'ємів 11. Синхронізацію обертання забезпечують шибери 7 зі своїми повзунами 10 і радіальні пази 6 корпуса 4 і тангенціальні пази 9 ротора 5. Рідина через впускний колектор 12 і канали 14 в роторі 5 засмоктується в робочі об'єми 11 і нагнітається у випускний колектор 13. Канали 14, проходячи навпроти впускних 12 і нагнітальних колекторів 13 на опорі обертання 3, розподіляють впуск або нагнітання рідини, тобто виконують функцію золотників- розподільників. Для зміни ексцентриситету вісь 2 може поступально вертикально переміщатися по пазу 16 у блоці 1 . Шток 17 діє на вісь 2 зусиллям від привода 18.

Висновки 3 дослідження i перспективи подалышого розвитку у даному напрямку. Доцільно на тепловозах для охолодження радіаторів дизеля застосовувати гідравлічні біроторно шиберні машини. Керування обертами гідромоторів здійснювати регулюванням продуктивності гідронасосів способом зміни ексцентриситету взаємного розташування ротора та корпуса, що сприяє підвищенню ККД гідропривода. 


\section{Список використаних джерел}

1. Галкин, В.Г. Надежность тягового подвижного состава [Текст] / В.Г. Галкин, В.П. Парамзин, В.А. Четвергов. - М.: Транспорт, 1981. - 184 с.

2. Тепловоз ТЭП60 руководство по эксплуатации и обслуживанию [Текст]. - М.: Транспорт, 1975. - 384 с.

3. Быков, В.Г. Пассажирский тепловоз ТЭП70 [Текст] / В.Г. Быков, Б.Н. Морошкин, Г.Е. Серделевич [и др.]. - М.: Транспорт, 1976. - 232 с.

4. Тепловозы. Конструкция, теория и расчет [Текст] / под ред. Н.И. Панова. - М.: Машиностроение, 1976. - 544 с.

5. Черкасский, В.М. Насосы, вентиляторы, компрессоры [Текст] / В.М. Черкасский. М.: Энергоатомиздат, 1984. - 416 с.

6. Теория механизмов и машин [Текст] / под ред. К.В. Фролова. - М.: Высшая школа, 1987. $-496 \mathrm{c}$.

7. Пат. 43282 А України, МПК 7 F02B53/00, F01C1/00, F04C2/00, F04C18/00. Роторна машина Чубикало М.Б. (варіанти) [Текст] / Чубикало М.Б. (Україна). - № 2001064078; заявл.14.06.2001; опубл. 15.11.2001, Бюл. № 10. - 10 с.

8. Пат. 50647 А України, МПК 7, F01C1/348, F02B55/00, F03C2/00. Роторна машина Чубикала М.Б. [Текст] / Чубикало М.Б. ( Україна ). - № 2009070790; заявл.24.07.2009; опубл. 25.06.2010, Бюл. № 12 - 9 с.

Рецензент д-р- техн. наук, професор А.П. Фалендиш

Чубикало Михайло Борисович, канд. техн. наук, доцент кафедри теплотехніки та теплових двигунів Української державної академії залізничного транспорту. Тел.: (057) 730-10-28. E-mail: chubykalom@ rambler.ru

Michael B. Chubikalo, cand. of techn. sciences, assistant professor of teplotehnika that teplovi dvigunov Ukraine State Academy of Railway Transport. Tel.: (057) 730-10-28. E-mail: chubykalom@ rambler.ru 